\title{
Jesus in the Dumping Sites: Doing theology in the overlaps of human and material waste
}

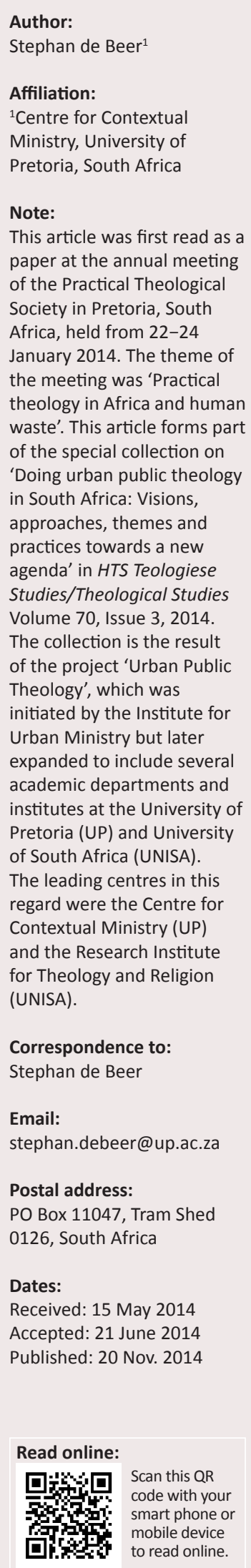

Jesus' option for the poor should be reclaimed in a clear theological and ecclesial option for the dumping sites of our cities and towns. That is the basic proposal of this article. Reflecting upon three different dumping sites - different in size, age and history - this article will explore the central thread of material and human waste, often dealt with almost as synonymous, concentrated and overlapping in these marginal spaces. It will additionally explore the theological and ecclesial challenges, but also possible opportunities, visions and gifts presented by them. The paradoxical (and sometimes toxic) interconnectedness between waste management and sanitised cities will be considered, as well as its relation to mediating or denying human dignity. The stories of Smokey Mountain in Manila, the Zabbaleen community in Mokattam Village, Cairo, and the Hulene Dump in Maputo, will be presented as part of this reflection. They will be read as mirrors to the proliferation of similar dumping sites on the fringes of South African cities. An outline is offered for a theological-ecclesial praxis emerging from the dumping sites, as well as a retrieval of possible contributions from these sites to the broader urban public theological reflection.

\section{Introduction}

The structure of this article involves embarking on a small journey and reflecting on three different dumping sites, where material and human waste overlap. Its purpose is to discover vocation, the gift of informality and the quest for justice, in fragile places outside the city's walls. The proposal is to reclaim Jesus' option for the poor in theological, ecclesial and urban development terms.

The article will pay brief visits to Smokey Mountain in Manila (cf. Beltran 2012), the Mokattam Village in Cairo, and the Hulene Dump in Maputo, and then seek to translate that back into similar spaces in our own context.

The basic question of this article is not what can we do for the dumping sites but what can we learn from them, in order for our own theological-ecclesial-urban praxis to be transformed?

The waste of the world is the treasure of God, whether material or human waste. This is beautifully captured in the reflections of Father Juliao Mutemba, who worked with people in the Hulene Dump in Maputo, before he abruptly died at the age of 42 of a heart attack. This article is dedicated to him. He writes:

When Jesus and his disciples left the Hulene dump and came out in the beautiful city with all its cars, $\mathrm{He}$ stopped and told his disciples that those who they just met at the dump will inherit the kingdom of God. (Mutemba 2008)

This echoes the apostle's assertion in 1 Corinthians 1:27-28 (NKJV 1982):

But God has chosen the foolish things of the world to put to shame the wise, and God has chosen the weak things of the world to put to shame the things which are mighty; and the base things of the world and the things which are despised God has chosen.

Building upon this premise I seek to discover Jesus in the dumping sites, opting for the poor, immersed in the overlaps of material and human waste.

\section{Jesus outside the city}

Dumping sites are prophetic signs of what is wrong with our society - they are places where humans are discarded as waste together with toxic materials, dirty needles and wasted food; and a sign of the grossest possible failure of creation in its most vulnerable state - unsustainable both ecologically and in terms of human well-being.

How to cite this article: De Beer, S., 2014, 'Jesus in the Dumping Sites: Doing theology in the overlaps of human and material waste', HTS Teologiese Studies/Theological Studies 70(3), Art. \#2724, 8 pages. http://dx.doi.org/10.4102/hts.v70i3.2724

Copyright: @ 2014. The Authors. Licensee: AOSIS OpenJournals. This work is licensed under the Creative Commons Attribution License. 
This is the place 'outside the city' where waste, lepers, criminals and outcasts have found co-habitation since the earliest times. It is in stark contrast to the capitalist city in all its flourishing, found in corporate headquarters and shopping malls and security estates, and in equally stark contrast to the religions of popular culture, with their successful branding, following the methods of the past empire.

In its position of stark contrast, the place 'outside the city' potentially represents another movement, often invisible, often discarded, often hidden behind piles of waste; but sometimes vocal, sometimes vigilantly resistant, sometimes boldly provocative; inviting us to discover another face of Jesus, another theology, another ecclesiology, and a different city.

It was outside the walls of the city that Jesus suffered death and where Peter suggested Jesus followers should be in solidarity.

Orlando Costas (1982) writes, in Christ outside the gate, about missions beyond Christendom - speaking of Jesus who encountered suffering and death outside the city, in solidarity with human and material waste. Costas evokes the reader to mission, in line with Peter's suggestion, that will follow Christ outside the gate of the city, there to be found in solidarity with all those discarded beyond the city's walls, finding new expressions of faith and community outside traditional theological, ecclesial and urban institutions.

On Thursday 09 January 2014 Foster Rivombo was shot and killed by a Metro Police officer for resisting his stock being taken away from him in a raid on informal traders in the city of Tshwane (Eliseev 2014; Van Zuydam 2014). He was killed for wanting to make an honest living, but doing so informally, because inside the gates of the city there is no access for the likes of him.

And yet the eventual killing, labelled as an isolated incident by municipal spin-doctors, was only the result of a tense build-up, over several months, between Metro Police and traders in the inner city of Tshwane. The Executive Mayor and his office decided to launch Operation Clean-Up to curb informal trade in the inner city with the idea of bringing more pedestrian traffic, or feet, to the city (Van Zuydam 2014). That in itself raises questions, as there is no lack of feet in the city, but the feet the Mayor wants are different feet; the feet of money and the middle-class. As a result traders' stock was confiscated and fines were levied for its return. Only a very limited number of licences are available for informal traders in the inner city, and very little infrastructure is made available to this very vibrant economic sector of society. Similar clean-up operations were conducted, over the months of late 2013 and early 2014 in Cape Town and Johannesburg. In the case of Johannesburg, the Constitutional Court had to rule at the end of last year in favour of the informal traders to be returned to the streets and to continue with their economic activity, even after the local municipality confiscated their goods and prohibited them from trading (SAPA 2014). The death of Rivombo is not an isolated incident but the result of a climate being created against the presence of informal traders in the city from the highest office to the local metro police officer. Thus, moral responsibility for his death should probably also lie then with the person of the Executive Mayor.

City authorities constantly act in contravention of the Constitution, both in its spirit and letter, in relation to informal traders, informal housing, and people living and working on dumping sites around our city. Political decisions, corporate desire and public sentiment, for so-called decency, collude to create two cities: a city inside the gate and a city that is inaccessible to the poor. Those occupying the dumping sites of cities around the globe, which is the focus of this article, and also people occupying various positions of informality, belong to the second city. Discarded as waste and excess and yet, theologically, maybe the apostle Paul and the stories of Manila, Cairo and Maputo will help us consider this other city - outside the gate, the second city is not just a city of exclusion, but also a city that is waiting, bidding, surprising, discovering, evoking, and gifting.

In this city outside the gate there are three things to be discovered - vocation, the gift of informality and the quest for justice.

\section{Discovering vocation: From garbage collectors to evangelists}

\section{The story of garbage collectors in Cairo}

Zabbaleen, in Egyptian Arabic, literally means garbage people. Today it refers to the 50-70 000 informal garbage collectors living in seven settlements across Cairo. The largest and most well-known of these 'garbage neighbourhoods' is the Mokattam Village with about 20-30 000 people, 90\% of whom are Coptic Christians (Assad 1998).

When you enter the Mokattam Village it leaves an overwhelming and lasting impression on all your senses: here is a sprawling urban neighbourhood with almost 30000 people. Through narrow alleyways you have to compete with little trucks collecting garbage, children on their bicycles, women and men crossing the streets, and various activities related to a vast recycling operation performed daily by the Zabbaleen. On the ground floor of their properties the collected garbage is sorted, and the space is shared with pigs that form an integral part of the whole recycling system, and in the apartments above this the people themselves live. Although people now reside in much more formalised structures, than was the case in Smokey Mountain or still is the case on the Hulene Dump, living conditions remain hazardous with high infant mortality rates of 117 deaths per 1000 births, compared to 45.6 deaths per 1000 births in the rest of the country (cf. Fahmi \& Sutton 2006:814).

It is a community outside the gate of the city which is, so to speak, stigmatised for consisting of the garbage collectors of the city, who are destined to be this and nothing else.

But, says Father Samaan, priest of the St. Simon Coptic Orthodox Church in the Mokattam Village: 'When Jesus appears somewhere that changes the whole society' (Hybels 2010). Hybels (2010) writes that ' $[h] \mathrm{e}$ is not speaking theoretically. He's describing what he's seen'. 
Initially these settlements were far more informal than they are today. It is said that only after the establishment of the Coptic Church in the Mokattam Village, in 1975, the people started to build with more permanent materials, 'such as bricks, for their homes' (Assad 1998). Today there are seven beautiful cave churches built into the Mokattam Mountains. The largest church, which also happens to be the largest church in the Middle East, is the Monastery of St. Simon the Tanner, which consists of an amphitheatre with the capacity to seat 20000 people (Iskander 2010). Once you leave the dense settlement, where the Zabbaleen reside, you enter through gates into the terrain of the Monastery of St. Simon - and you are immediately greeted by immense beauty and tranquillity. This is one of the largest churches in the world, and most beautiful; built for, with and by a community of garbage collectors in a predominantly Muslim country.

Initially bathed in shame, indignity and exclusion, the saturating presence of Coptic Christianity in the Mokattam Village slowly transformed this village from shame to dignity, from exclusion to vocation, from garbage collectors to evangelists, and from rejects to God's agents. This was through the patient care of Father Samaan and others, as an embodiment of a loving God.

One garbage collector, still collecting garbage in the surrounding neighbourhoods of Cairo, says of himself: 'I am not a garbage collector anymore; I am an evangelist now.' Largely unknown outside of Cairo the story, of the Zabbaleen and the Coptic community in Mokattam, has become one of the most profound expressions of the Christian faith; yet it is too often hidden behind layers of garbage, prejudice and theological colonialism. Theirs is a spiritual vocation (evangelists of the city), an environmental vocation (caring for the oikos of Cairo) and an ecclesial or communal vocation (building a healing community of faith), practiced from the bottom up, from outside the gate pushing its way back in on donkey carts.

\section{The story of Ben Beltran in Manila}

Father Ben Beltran is a Roman Catholic priest from the Philippines, who obtained his doctorate in systematic theology in Rome. A newspaper reporter interviewed Father Beltran on his experience in Rome, '[ $h] \mathrm{e}$ says he became an expert in the field, but lost interest in its relevance to day-to-day faith. He says he became sick and tired of the world and of himself' (Melican 2013). After obtaining his doctorate, he then decided to return to his home country and for 30 years he lived on Smokey Mountain, Manila, with 25000 garbage dwellers on a dumping site of 20 hectares. He became their priest. He says it himself in these words:

I did not go there to help, but I went there to help myself. It was not about me going there and saying that I came from Rome and imposing my thinking on them. I was humbled by them. I went there not to save the scavengers, but to allow scavengers to save me. (Melican 2013)
In an interview with the Inquirer, Beltran recalls the first time he set foot on Smokey Mountain, describing it as a 'spinetingling experience'. He is quoted as saying:

I saw, smelt and felt the 20 hectares of garbage dump spread before my eyes. And then there were the children and other people scavenging for stuff they could sell among the trash. (Melican 2013)

Over a 30-year period Beltran befriended the people of the dumping site, listened carefully to their concerns, organised the community, staged protests against the government, started nutrition and educational programmes, and became instrumental in mediating a massive housing project and green businesses. These efforts would enable the dumping site to be transformed from garbage heap to residential neighbourhood. His conclusion after this time is simply 'I have learned that God is speaking through the poor. You should not come to the poor to save them, but to save yourself' (Roberts 2010).

Not only do the garbage dwellers of Cairo discover their vocation in the dump, but the priest-theologian from Manila says he is saved by the poor, on Smokey Mountain he finds his vocation: the church and theology are not called to save the poor, but they first need to allow the poor to save us.

He discovered his own vocation not in the theological encyclicals and classes of Rome, but in the dumping sites of Manila. He discovered Christ, not inside the gates of capital and power and intellectual prowess, but outside the gate where God chose those who were despised to gift him with a vocation.

\section{The story of Juliao Mutemba in Maputo}

Father Juliao Mutemba spent much of his time on the Hulene Dump in Maputo. He was an Anglican priest in the parish of St. Barnabas, Bagamoyo, founder of Leadership Foundation Mozambique and officer with the Christian Council of Mozambique. Juliao mediated between different communities and churches, between institution and grass roots, and between those in power and the poor. However, he found his greatest joy in his time spent with the garbage dwellers on the Hulene Dumping site, Maputo's largest such site. Daily 800 tons of garbage is dumped on this site (Van Baalen 2013). Hundreds of people, including the elderly and children live and eat off the dump.

This was the subject of his ongoing master's dissertation, entitled 'A Theology of Garbage: discovering the hidden treasure'. And then, unexpectedly, in May of 2013 the 42-year-old Juliao died of a heart attack. Some time ago, he reflected on the life of Calisto Vanquina, someone who became his friend and who lived on the Hulene Dump. He writes about Calisto in this way:

And you Calisto, you were given a desert to be your bed, the sky was your top roof, bulldozers were your alarm to woke you up. Now that you, the tree of the desert have fallen down, where will the worms find shade, where will the kids learn stories, who will pass on the knowledge about the past? Who will teach us how to survive in crisis, how will we know the history of the army which he used to tell? (Mutemba 2011) 
Juliao remembers Calisto's own words: 'I remember, you Calisto, you once said, "Living in the dump is part of God's favour for me, otherwise, even a place like this I would not have"' (Mutemba 2011). The dumping site of Hulene became home, shelter and refuge to someone with nowhere else to go. Juliao's conclusion about the life of Calisto is this:

$[I] \mathrm{t}$ becomes clear that, we looked at Jesus in Calisto, 'we despised him, and rejected him; he endured suffering and pain. No one would even look at him - we ignored him as if he were nothing (Isaiah 53:3). (Mutemba 2011)

Not only are garbage dwellers discovering their own vocation; not only do clerics and theologians discover vocation afresh outside the city gates on dumping sites. Conversely, in the words of Juliao himself dumping sites become, by default not by design, home and refuge to the many who cannot access safe spaces inside the city gates.

This provides an important, and alternative, entry point to the city and requires an epistemological shift:

- in affirming the dumping site as home

- in discovering the rich treasures hidden away in its layers of garbage

- and, as we do so, by asking ourselves with the people of the dump: what kind of world have we made and allowed, also as theologians and Christian practitioners, if dumping sites become home; if that is the only safe space in the city? How did it become as bad as it is in the cities of our world? And where were God and God's people and theologians when it happened to become this way?

\section{The gift of informality: Indigenous solutions, communal well-being}

A further discovery is the gift of informality. There is not enough space in this article to reflect on the nature of informality in great depth. But informal settlements, informal enterprise and informal educational infrastructure, often offer gifts to society at large and to the most vulnerable members of society in particular, that are not able to be offered by formal society. Formal society and its structures are generally too disconnected from the city outside the gate to make sufficient sense of it, to be qualified or able to imagine, and therefore construct the kinds of innovations that could set free those living outside the gate. It requires the gift of agency from within those living outside the gate, often in partnership with those going beyond the gate in prophetic solidarity.

\section{Unparalleled track record of the Zabbaleen community: Towards a radical green economy}

The people of the Zabbaleen community have been internationally recognised for their unparalleled successes with recycling waste in the city of Cairo. They are able to recycle $80 \%$ of garbage that they collect, in comparison to the $20 \%-25 \%$ recycling that is effected by sophisticated western operators (Fahmi 2005:158; Fahmi \& Sutton 2006:820). Their way of collecting and recycling garbage is culturally aligned to the neighbourhood practices in and around Cairo, and is economically much less costly for both the city and the citizens of the city. Environmentally, economically, culturally and from the perspective of social inclusion the Zabbaleen model is difficult to compete with by any other community.

And yet, despite these highly successful efforts by the Zabbaleen community, municipal authorities in Cairo in 2003 decided to undermine this community and award contracts worth $\$ 50$ million to three multinational garbage disposal companies from Spain and Italy (Fahmi \& Sutton 2006:821; Rashed 2003a, 2003b). This was a clear denial of the activity of the local people and their particular asset and gift to the city.

When the multinational corporations, with their sophisticated and advanced infrastructures, started to collect garbage from local neighbourhoods, they were only able to recycle $20 \%$ of what they collected, as opposed to the $80 \%$ recycling rates of the Zabbaleen. Instead of doorto-door collection as is carried out by the Zabbaleen, central garbage containers were provided, which often inconvenienced residents, in terms of access. In some cases narrow alleyways were not accessible to the mechanised equipment of the multinationals, which meant that they had to subcontract the Zabbaleen to ensure garbage collection. This did not work out in the end because the Zabbaleen were underpaid, earning much less from being subcontractors than from collecting the garbage from the same streets themselves. Also the cost of collection increased significantly in comparison to the service rendered by the Zabbaleen. Once these contracts were awarded, the Zabbaleen were not compensated for loss of income, which obviously affected the sustainability of the Zabbaleen enterprise (Fahmi \& Sutton 2010:1772; Rashed 2003a, 2004). Environmentally, culturally, economically and socially, the entry of multinationals from the global North, into the reality of Cairo, negated the local gift of the Zabbaleen and increased the vulnerability of an already vulnerable community significantly.

Koyama (1974:62-70), 40 years ago, spoke of the inefficient God and the technological efficiency of our age, and the shifts from ox-cart to supersonic aircraft or, as in the Zabbaleen people, from donkey carts to sophisticated multinationals. And yet it becomes clear that efficiency does not necessarily equate to effectiveness or impact, neither environmentally nor economically or socially. A tension developed between universal technological advancement and forms of local culture, society and religion. The Zabbaleen community finds itself in the middle of this tension, and bids us ask critical questions of an uncritical set of models of efficiency that seem, at face value, to be advanced. Yet, in terms of building humane cities, inclusive and owned from below, this might prove to be to the contrary in their inability to embrace vulnerability, to mediate justice, or to foster earthfriendly practices. 


\section{Arising from the ashes: The story of Smokey Mountain}

For 40 years 25000 people lived on the large dumping site of Smokey Mountain on 2000000 tons of garbage. The people living on the dumping site also lived off the garbage. For 30 years of this period Father Ben Beltran was the local parish priest. Through consistent organising of the community over many years, the ministry of word and sacraments, the creation of multiple base ecclesial communities, educational programmes, recycling enterprises and leadership development processes, a solid foundation was laid for a self-sufficient local community to be birthed right on one of the world's most severe dumping sites. The community of Smokey Mountain did not give up on finding more liveable and humane alternatives, despite forced removals of the people from Smokey Mountain, their subsequent return to Smokey Mountain as the only home and livelihood they knew, death threats against Father Beltran, and the lack of political will to find lasting and sustainable solutions for those living there. Beltran, in an interview, is quoted as saying:

The people organised themselves and mounted rallies and demonstrations to press for their demands, such as proper housing. The dump was eventually closed, and medium-rise buildings were built as housing for the residents. (Melican 2013)

In 1993, after 30 years of advocating for this, the National Housing Authority of the Philippines signed a contract with a construction company for the development of low-income housing, serving the people who lived off the Smokey Mountain dumping site. Instead of leaving them outside the city wall, the efforts of people from below ensured that the political will of Manila's authorities changed towards an inclusionary approach and the most marginalised people of the city were offered decent and sustainable access to the city. This was due to the prophetic solidarity of Father Beltran's pastoral ministry in this area, as well as other vocal and passionate civic and non-profit leaders. The Smokey Mountain Development and Reclamation Project (SMDRP) was formed and after being temporarily relocated to allow for construction, former inhabitants of Smokey Mountain are now living in permanent housing in what is today known as Paradise Heights (Ramos 2007).

In addition to decent low-income housing there are play spaces for children and other community infrastructures, and today there are waste management programmes, owned and run by local people. Also, there is a project to plant a million trees in Manila and E-trading enterprises connecting people living in urban slums with poor farmers and fisher men. This bridges not only the digital divide, but connects people beyond the walls that kept them from having access to the city inside the gate. There is also a 'green church' Father Beltran is constructing on what used to be Smokey Mountain (Ramos 2007; Roberts 2010). Indigenous solutions imagined between all sectors of society can mediate communal wellbeing and become a global example of good practice.

\section{The ongoing discovery in Hulene}

Juliao passed on too quickly to tell us all that he has discovered. But he left a legacy - an invitation to others to stand in solidarity with the dump and to learn from those living there and from the dump itself. This in itself became the gift of Hulene to the church - as it is prompting the church and practising theologians in the city of Maputo, and elsewhere, to find languages to speak of God and grace and love and justice, in the context of the dumping site and of those living and dying there. Additionally, it prompts them to consider what an authentic and appropriate urban theological response should be; and how best urban theologians should accompany and inform processes of planning and policy-making that take realities such as the Hulene Dump seriously.

In contrast to this the Smokey Mountain story is a miracle story of transformation from below in partnership with authorities from above, showing what is possible, and the Zabbaleen story one of global best practice perpetually at risk because of a lack of political buy-in into the gift that the Zabbaleen community has become. Hulene in Maputo provides a prior invitation as it suggests that we cannot, as church and theology, discover the gift of informality, the possibility of indigenous solutions or the joy of communal well-being, if we fail to deliberately find new spaces for doing theology, new interlocutors to shatter our confident constructs and new visions to help us re-imagine our theological-ecclesialurban praxis, in solidarity, outside the city gate. Hulene and the dumps, or other excluded spaces in our midst, invite us to consider the innovations of the Spirit, not only in a spiritual sense, and how it could possibly break into the spatial and physical realities of our cities.

\section{The quest for justice: Constructions from below}

Apart from a discovery of vocation or the gift of informality, these sites remain prophetic spaces reminding us of the harsh inequalities of our cities, how unsustainable they are environmentally, and how exclusive they are socially. Edward Soja (2010:31) speaks of this as the production of unjust geographies' and David Harvey (1997:84) reflects on it when he thinks about 'the urbanization of injustice'.

The quest for justice is raised from the dumping sites, and theologically we are challenged to consider constructions of justice from below and in solidarity with such communities.

\section{Replication and legislation: Building on just alternatives in Manila}

The story of Smokey Mountain speaks of the possibility of just alternatives, if the right kinds of pressure and partnerships are sustained from below, in conjunction with political and corporate will brokered from above. It is former president Ramos (2007) who recognises the fact that the story of Smokey Mountain should not remain isolated, but should 
accelerate the quest for justice in all such communities locally, regionally and globally. He explains this as follows:

With ... accolades from international experts for SMDRP as a Philippine-designed 'global best practice,' now - not tomorrow - is the time to relieve the miseries of the poor still located on garbage dumpsites and other life-threatening areas. New reclamation and land use legislation is urgently called for ... (Ramos 2007)

Ramos is urging for the replication of the Smokey Mountain story on garbage dumping sites and other such areas all over the Philippines, using the precedent and principles used to transform Smokey Mountain. Simultaneously he pleads for legislation around land use and reclamation that would enable such replications.

The poor are often kept outside the gate because of inhibiting and disabling policy perpetuating a lack of access and proximity to sources of power or livelihood. Ramos argues for policy changes that would enable the liberation of poor people everywhere, particularly in terms of their access to urban land and space.

This echoes the work of someone like Henri Lefebvre (1996) who conceptualised the 'right to the city' approach, stating:

The right to the city ... should modify, concretise, and make more practical the rights of the citizen as urban dweller ... and user of multiple services. It would affirm, on the one hand, the right of users to make known their ideas on the space and time of their activities in the urban area; it would also cover the right to the use of the center, a privileged place, instead of being dispersed and stuck into ghettoes (for workers, immigrants, the 'marginal', and even for the 'privileged'). (p. 34)

The 'right to the city' actively seeks to break down the barriers between the first and second city, or the city inside and the city outside the gate. That is what Ramos, Father Beltran and the people of Smokey Mountain, worked for relentlessly, and embodied so beautifully.

\section{Vulnerability and justice: The Zabbaleen}

Although hailed by international organisations, the Zabbaleen community in Cairo is still an excluded community. When multinationals are awarded contracts threatening the livelihoods of local people, it happens without any compensation to local people for the losses they suffer.

In 2009 when the H1N1 influenza (or swine flu) broke out in Mexico, the Egyptian parliament ordered the culling of the entire population of pigs in Egypt. This despite the fact that there was no incidence of the flu in Egypt, and of the 169 people who died as a result of the epidemic, all but one person died in Mexico. International organisations condemned the killing of pigs, as there was no evidence that the flu could be related to pigs to start with, but this also threatened the livelihoods of the Zabbaleen and other communities significantly, as pigs play an integral part of the whole recycling process (Fahmi \& Sutton 2010:1774; Fraser 2009; Kahlil 2010; Nadim 2009). Within days of pig culling it was reported that garbage was piled high on the street corners of Cairo, with resultant health risks (cf. Slackman 2009:1).
In addition to this, there are ongoing threats to remove the Zabbaleen from the Mokattam Village to a place 25 kilometres outside of the city (Fahmi \& Sutton 2006:820; Fahmi \& Sutton 2010:1771, 1774). This would make the neighbourhoods from which they collect garbage far less accessible to them, and seriously affect their cost and income. It would also have hazardous repercussions for the neighbourhoods serviced by them. In addition, it has the potential of destroying the roots of a community that has embedded itself culturally, socioeconomically and religiously in Mokattam. Instead of seeing them as an asset to be guarded and integrated fully into the life of the city, as has been the case in Manila, the Zabbaleen remains at risk outside the city gate.

\section{A call to prophetic solidarity: The challenge of Hulene}

Once again Hulene in Maputo offers a prior invitation: there is no miracle story here, nor an emerging good practice, but simply a community of very vulnerable people living off the dump. In February it was reported that hundreds of rounds of live ammunition, potentially explosive, were found on the dumping site where children and adults live or scavenge for food or other material (IOL 18 February 2013). Van Baalen (2013) reports on it thus:

Today, Hulene extends over an area of 17 hectares. According to Hafido Abacassamo, former Director of Waste Management at the municipality, Hulene is the only solution at the moment. 'The landfill is causing major problems for the environment, such as toxic methane gas releases, fires, disease and security... But it is a problem that the city needs. Without a place where you can dump the waste, the municipality cannot guarantee any waste collection at all!' The dump lacks the resources needed for effective and sustainable waste management.

There is no sophisticated organisational infrastructure here, such as that developed by Father Beltran, or the indigenous organising and infrastructure of the Zabbaleen. People are completely exposed to the elements or the inaction of the political elite who are far removed from the realities of the dump. Although politicians imagine the clearing up of the dump by 2014, most commentators doubt that anything will happen soon. Visions of clearing up the dump also exclude viable plans for the inclusion and livelihoods of the dump's current inhabitants. A lack of resources, a lack of know-how and a lack of will combine to prevent indigenous solutions, or just alternatives for those living off Hulene and those affected by it in the surrounding neighbourhoods (cf. Van Baalen 2013).

How do we practice theology or do church, precisely in places such as Hulene, where toxic methane gas releases and the breaths of toddlers compete for life?

\section{Cry of the earth: The solidarity of the poor}

It is Boff (1997), in Cry of the earth, cry of the poor, who strikingly shows how global and local oppressions affect both the poor and the earth, and often in relation 
to each other. Soja $(2010: 52)$ refers to the assertion of the Environmental Justice Movement (EJM) in the United States of America, that the poor and minorities in that context 'suffer disproportionately from air and water pollution and the siting of hazardous or toxic facilities'.

In the overlap of material and human waste, on the dumping sites of the world, these cries merge and invite us into solidarity with both the poor and the earth and provoke the following questions:

- How do we speak of God, or how do we celebrate communion, with integrity and with dignity, on a dumping site of 2000000 tons of garbage with 30000 human inhabitants?

- How do we celebrate communion, or speak of God, in our churches, knowing there is a city outside the gate?

- How do we allow the earth and the poor, their cries and their gifts, to transform how and where we do theology, how and where we are church, how and where we shape our cities?

- With whom do we walk?

The stories from Manila, Maputo and Cairo connect communities living on dumping sites globally with each other. In South African cities the sheer size of dumping sites and scavenging communities might not be as big as in Cairo or in Manila, but the depth of vulnerability and exclusion is the same. The face of dumping sites in South Africa is often that of children and women (cf. Benjamin 2007; SABC 2013; Samson 2010) and doing urban theology in such spaces would need to carry their voices and their faces. The cry of the earth and the cry of women, children and men often comes from dumping sites on the fringes of South African cities and towns. They come from Foster Rivombo and his family, from informal traders and homeless communities and from recyclers reclaiming hidden resources from the discarded materials of a city of capital.

\section{The poverty of church and theological education: A call outside the gate}

We may be richly endowed with property, famous theological institutions, efficient programmes and wellexecuted worship services, and yet, if we fail to connect to the city outside the gate - to discover vocation, the gift of informality and the quest for justice in these places - where the cry of the earth and the cry of the poor merge and where the majority of the world's population live, are we not profoundly poor? The dumping sites in cities around the world are the homes and places of income of the people who live within them. Such places expose the poverty of church and theological education and the impotency of public policy and city planning.

The subheading of this article is 'doing theology in the overlaps of material and human waste'. What could this concretely mean? I conclude by offering a few suggestions, which are nothing new perhaps, but invite renewed consideration about places of material and human waste:

- Firstly, these places provoke the discovery of vocation in new places and from different people, outside the gate of the city. They enable the dumping sites to redeem theology, the church and the city from its enslavement to capital and the empire.

- Secondly, they provoke the discovery of the gift of informality, namely indigenous solutions, the poor as interlocutors and teachers and the art of fostering communal well-being.

- Thirdly, they encourage the building of partnerships of prophetic solidarity with those outside the gate, together to discover and work for socio-economic, political and environmental justice in the city, and enable our mutual freedoms.

- Fourthly, they enhance the consideration of whether or not the ways in which we do theology today, in most of our institutions of theological education, such as the content of curricula and the methodologies of learning and teaching, are not simply expressions of the city inside the gate, complete strangers to the second city, the city outside or the city of informality.

- Fifthly, they extend the invitation, or perhaps show the necessity, for a theological-ecclesial-urban conversion mediated by practising a clear option to stand in and with, and to be converted by the city outside the gate.

We are invited to consider vocation with the people of Mokattam Village in Cairo, to discover the gift of informality with them and the people of Smokey Mountain and to renew our commitment to justice, with the garbage dwellers of Hulene, or Atteridgeville or Mamelodi. Thus, justice for all, justice for the poor and justice for the earth.

Juliao Mutemba (2011) reflects on Hulene and the life of Vanquina:

You Hulene dump, the mother of the poor, you are most loved by the saints of the city; for you provide for food and shelter to human beings, birds, dogs and worms. 'How does one love and long for a mother whose breasts ooze dirty waters ... diluted with blood? How does one feel knotted to such a mother?' ... Talking of Vanquina is to remember of someone who struggled to keep ardent the flame of life, independently of the condition he found himself in, in the warmth of his mother dump.

Could that be the invitation to church, theology and urban praxis: to struggle to keep ardent the flame of life, despite the conditions in which we find ourselves, in the warmth of our mother dump? Or have we lost the ability to place ourselves in places of death, where, against all odds, we can find life, and with many others keep alive the flame of life?

\section{Acknowledgements}

I wish to acknowledge Fr Juliao Mutemba who was my friend and host into the Hulene Dumping site, Fr Ben Beltran for graciously sharing his story with us, and Fr Maximous el-Antony for first exposing me to the Zabbaleen community of Cairo. 


\section{Competing interests}

The author declares that he has no financial or personal relationship(s) that may have inappropriately influenced him in writing this article.

\section{References}

Assad, R., 1998, Upgrading the Mokattam Zabbaleen (Garbage Collectors) Settlement in Cairo: What Have We Learned?, paper presented at the Macarthur Consortium on International Peace and Cooperation Symposium on the Challenge of Urban Sustainability, University of Minnesota, Minnesota, May.

Beltran, B., 2012, Faith and struggle on Smokey Mountain: Hope for a planet in peril, Orbis Books, New York, NY.

Benjamin, S., 2007, A rapid assessment on scavenging and waste recycling work done by children in South Africa, Department of Labour, in cooperation with the International Labour Organization, Pretoria.

Boff, L., 1997, Cry of the earth, cry of the poor, Orbis Books, New York, NY

Costas, O., 1982, Christ outside the gate: mission beyond Christendom, Orbis Books, New York, NY.

Eliseev, A., 2014, 'Analysis: never forget Jan Rivombo', Daily Maverick, viewed 15 January 2014, from http://www.dailymaverick.co.za/article/2014-01-13-analysisnever-forget-jan-rivombo/\#.VBHOezsaLIU

Fahmi, W., 2005, 'The Impact of Privatization of Solid Waste Management on the Zabbaleen Garbage Collectors of Cairo', Environment \& Urbanization 1(2), 155-170.

Fahmi, W. \& Sutton, K., 2006, 'Cairo's Zabbaleen Garbage Recyclers: Multinationals' Takeover and State Relocation Plans', Habitat International 30, 809-837. http:// dx.doi.org/10.1016/j.habitatint.2005.09.006

Fahmi, W. \& Sutton, K., 2010, 'Cairo's Contested Garbage: Sustainable Solid Waste Management and the Zabbaleen's Right to the City', Sustainability 2, 1772, 1774 http://dx.doi.org/10.3390/su2061765

Fraser, C., 2009, 'Egypt slaughters pigs to stop flu,' BBC News, viewed from http:// news.bbc.co.uk/2/hi/middle_east/8024946.stm

Harvey, D., 1997, 'The environment of injustice', in A. Merrifield \& E. Swyngedouw (eds.), The Urbanization of Injustice, pp. 65-99, NYU Press, New York, NY.

Hybels, L., 2010, 'When Jesus comes, everything changes: An Advent experience in Cairo', Huffington Post Religion, viewed 12 January 2014, from http://www. huffingtonpost.com/lynne-hybels/a-stunning-transformation_b_799138.html

Iskander, R., 2010, 'The Monastery of Saint Simon (Simeon) the Tanner', in Tour Egypt, viewed 14 January 2014, from http://www.touregypt.net/featurestories/tanner.htm

Lefebvre, H., 1996, Writings on cities, transl. E. Kofman \& E. Lebas (eds.), Basil Blackwell, Oxford.
'Live ammunition found in Mozambique trash', IOL, 18 February, 2013, viewed from http://www.iol.co.za/news/africa/live-ammunition-found-in-moz-trash1.1472348

Kahlil, A., 2010, 'Swine Flu: Was it ever really a threat?' Egypt Independent, viewed 14 January 2014, from http://www.egyptindependent.com//news/swine-flu-was-itever-really-threat

Koyama, K., 1974, Water buffalo theology, Orbis Books, New York, NY.

Melican, N.R., 2013, 'Smokey Mountain saved me', in Inquirer, viewed 15 January 2014, from http://newsinfo.inquirer.net/382077/smokey-mountain-saved-me ixzz2qAI4LsAy

Mutemba, J., 2008, 'Hidden treasures on a dump', unpublished reflection, August 2008, accessible at the Centre for Contextual Ministry, University of Pretoria.

Mutemba, J., 2011, 'Dying like a dog', unpublished reflection, March 2011, accessible at the Centre for Contextual Ministry, University of Pretoria.

Nadim, A., 2009, 'Culling pigs in flu fight, Egypt angers herders and dismays U.N.,' The New York Times, viewed 14 January 2014, from http://www.nytimes. com/2009/05/01/health/01egypt.html?_r=0

'No Christmas joy for dumping site dwellers', SACB, 2013, viewed 15 January 2014, from http://www.sabc.co.za/news/a/55b7ac00425116a9bb99fb56d5ffbd92/NoChristmas-joy-for-dumping-site-dwellers

Ramos, F.V., 2007, 'Triumph of the Poor at Smokey Mountain (Part II)', viewed 13 January 2014, from http://www.rpdev.org

Rashed, D., 2003a, 'Cairo ceanup conundrums', Al-Ahram Weekly, viewed 17 January 2014, from http://weekly.ahram.org.eg/2003/661/eg6.htm

Rashed, D., 2003b, 'Trashed Lives,' Al-Ahram Weekly, viewed 17 January 2014, from http://weekly.ahram.org.eg/2003/624/fe1.htm

Rashed, D., 2004, 'Unfinished business', Al-Ahram Weekly, viewed 17 January 2014, from http://weekly.ahram.org.eg/2004/694/sc3.htm

Roberts, I., 2010, 'Father of Smokey Mountain - looking out for Mother Earth, its children and the residents of Smokey Mountain', in Inspirational Pinoy Boomer viewed 15 January 2014, from http://www.pinoyboomer.com/featured-beltran. htm

Samson, M., 2010, Organizing reclaimers in Tshwane, South Africa: Lessons from top down and bottom up experiences, Wiego Organizing Brief No. 5, Women in Informal Employment: Globalizing and Organizing (WIEGO), Cambridge, MA.

SAPA, 2014, 'Court rules in favour of informal traders', eNCA, viewed 16 January 2014 from http://www.enca.com/south-africa/court-rules-favour-informal-traders

Slackman, M., 2009, 'Belatedly, Egypt spots flaws in wiping out pigs', The New York Times, viewed 15 January 2014 , from http://www.nytimes.com/2009/09/20/ world/africa/20cairo.html?pagewanted=all\&_r=0

Soja, E., 2010, Seeking spatial justice, University of Minnesota Press, Minneapolis, MN.

Van Baalen, S., 2013, 'Down in the dumps: Maputo's mighty municipal landfill', in Think Africa Press, viewed 15 January 2014, from http://www.thinkafricapress com/mozambique/down-dumps-maputo-mighty-municipal-landfill

Van Zuydam, L., 2014, 'Traders threaten chaos over vendor's killing', Pretoria News, viewed 15 January 2014, from http://www.iol.co.za/news/crime-courts/tradersviewed 15 January 2014 , from http://wwW.iol.co.za/news/crim
threaten-chaos-over-vendor-s-killing-1.1631382\#.VAdnITsaLIU 